Meta

Journal des traducteurs

Translators' Journal

\title{
The Interpreter, the Monitor and the Language Arbiter
}

\section{Kayoko Takeda}

Volume 54, numéro 2, juin 2009

URI : https://id.erudit.org/iderudit/037675ar

DOI : https://doi.org/10.7202/037675ar

Aller au sommaire du numéro

\section{Éditeur(s)}

Les Presses de l'Université de Montréal

ISSN

0026-0452 (imprimé)

1492-1421 (numérique)

Découvrir la revue

Citer cet article

Takeda, K. (2009). The Interpreter, the Monitor and the Language Arbiter. Meta, 54(2), 191-200. https://doi.org/10.7202/037675ar

\section{Résumé de l'article}

La question de la confiance à accorder aux traducteurs et aux interprètes est débattue depuis longtemps dans la profession. Dans certains cas, un ensemble de procédures sont établies afin de susciter la confiance des clients et des utilisateurs. Au sein du Tribunal militaire pour l'Extrême-Orient (1946-1948), ces procédures ont pris une forme particulière. Pendant le procès, trois groupes différents sur les plans social et ethnique assumaient trois fonctions différentes dans le cadre du processus global d'interprétation : les Japonais interprétaient, les Américains d'origine japonaise contrôlaient, et les officiers militaires américains jouaient le rôle d' « arbitres » linguistiques qui tranchaient en cas de controverse. Les aspects sociopolitiques tels que la confiance, le pouvoir et le contrôle sont évidents dans cette structure hiérarchique. Dans de tels environnements politiques ainsi que dans d'autres que nous connaissons aujourd'hui, le besoin de faire confiance à l'interprète peut prendre le pas sur la qualité de l'interprétation.
Ce document est protégé par la loi sur le droit d'auteur. L'utilisation des services d'Érudit (y compris la reproduction) est assujettie à sa politique d'utilisation que vous pouvez consulter en ligne.

https://apropos.erudit.org/fr/usagers/politique-dutilisation/ 


\title{
The Interpreter, the Monitor and the Language Arbiter:
}

\author{
KAYOKO TAKEDA \\ Monterey Institute of International Studies, Monterey, USA \\ kayoko.takeda@gmail.com
}

\begin{abstract}
RÉSUMÉ
La question de la confiance à accorder aux traducteurs et aux interprètes est débattue depuis longtemps dans la profession. Dans certains cas, un ensemble de procédures sont établies afin de susciter la confiance des clients et des utilisateurs. Au sein du Tribunal militaire pour l'Extrême-Orient (1946-1948), ces procédures ont pris une forme particulière. Pendant le procès, trois groupes différents sur les plans social et ethnique assumaient trois fonctions différentes dans le cadre du processus global d'interprétation: les Japonais interprétaient, les Américains d'origine japonaise contrôlaient, et les officiers militaires américains jouaient le rôle d'«arbitres» linguistiques qui tranchaient en cas de controverse. Les aspects sociopolitiques tels que la confiance, le pouvoir et le contrôle sont évidents dans cette structure hiérarchique. Dans de tels environnements politiques ainsi que dans d'autres que nous connaissons aujourd'hui, le besoin de faire confiance à l'interprète peut prendre le pas sur la qualité de l'interprétation.
\end{abstract}

\begin{abstract}
The trustworthiness of translators and interpreters has long been an issue in the profession. In some cases, a set of procedures are established to ensure the trust of clients and end-users. In the International Military Tribunal for the Far East (1946-1948), such procedures took on remarkable form. During the trial, three ethnically and socially different groups of language personnel engaged in three different functions within the overall interpreting process: Japanese nationals as interpreters, Japanese Americans as monitors, and U.S. military officers as language arbiters who ruled on the disputed interpretations. Sociopolitical aspects such as trust, power and control are evident in this hierarchical structure. In such political settings, and in others seen today, the trustworthiness of the interpreter may override the quality of interpreting.
\end{abstract}

\section{MOTS-CLÉS/KEYWORDS}

Tribunal militaire international pour l'Extrême-Orient, moniteur, médiateur linguistique, confiance, pouvoir, contrainte

International Military Tribunal for the Far East, monitor, language arbiter, trust, power, control

\section{Introduction}

The trustworthiness of translators and interpreters has long been an issue in the ethics of the profession. Often professional practice itself can be seen as a set of procedures for gaining and maintaining the trust of clients and end-users. In interpreting, such procedures may include monitoring the work of interpreters. The best documented interpreter monitoring system is probably the one employed at the Nuremberg Trial. It was not used, however, as a means to police the interpreters' behavior, but rather as a way to ensure smooth operation of the interpreting arrange- 
ments in a formal international setting during the nascent stage of simultaneous interpreting. This view is confirmed by the fact that interpreting errors were sometimes corrected by the interpreters themselves who checked the daily transcript against the verbatim recording (Gaiba 1998: 71, 97-98). In other words, there was no separate authority responsible for the monitoring.

Around the same time, the much-less-documented interpreting arrangements at the International Military Tribunal for the Far East (IMTFE) involved quite a different monitoring system. Here, three ethnically and socially different groups of linguists ${ }^{1}$ engaged in three different functions in the interpreting process: Japanese nationals as interpreters, Japanese Americans as monitors, and U.S. military officers as language arbiters who ruled on the disputed interpretations. By drawing on the concepts of trust, power and control, this paper explores why the tribunal devised this unusual organization to address the language needs during the trial.

\section{Trust, power and control}

In an interpreter-mediated event, when different parties represent different interests, the party wielding the authority to select the interpreters will most likely avoid using interpreters who seem to have a conflict of interest, due to suspicions that they may act in "bad faith" to advance their own agenda. Such suspicions arise from the "power" that the interpreters are perceived to possess.

Anderson (1976: 218-221) argues that "the interpreter's position as the person in the middle has the advantage of power inherent in all positions that control scarce resources," and that the interpreter can monopolize the means of communication. Laster and Taylor (1994: 111) point to this "power" as the reason lawyers try to regulate and constrain the interpreter's role as "neutral machines or 'conduits'." The monolingual user's fear that interpreters may exercise such "power" to advance their own interests is not completely unwarranted. Examples of such interpreters include the one who deliberately misinterpreted for a Gaelic poet defendant in 18th century Ireland (Cronin 2002: 55), and the sign language interpreter in Ukraine who delivered her own political message on television while pretending to be interpreting the 2004 election results (Zarakhovich 2005).

The user's mistrust of the interpreter arising out of an absence of shared interest or affiliation has been discussed throughout the history of interpreting: William of Rubruck in the $13^{\text {th }}$ century suspected that his Armenian interpreters distorted their interpretation (Bowen 1995: 254-255); European embassies complained about the incompetence and disloyalty of Levantine dragomans in the Ottoman era (Lewis 2004: 25-26); and, in the 1820 trial of Queen Caroline of England, the defense was concerned about the impartiality of the Italian interpreter provided by the prosecution (Morris 1999: 19). In today's context of the Iraq war, the inventor of IraqComm, a portable two-way interpreting device, suggests that human interpreters are not entirely trusted and " $[\mathrm{t}]$ he interpreters may have their own political agenda" (Precoda quoted in Abate 2006).

In response to such concerns about trust, the party in power may establish a system to regulate and control the interpreter. Hermans (2000:4-7) discusses several historical examples such as interpreters during the European discovery of America and Oranda tsuji (Dutch interpreters) in 17th-19th century Japan to point out the 
"tight controls on translators and interpreters to guarantee their trustworthiness, to ensure that they speak exclusively with their masters' voice." Referring to the overseers of the dragomans in Ancient Egypt, Pym (1998: 186) also draws attention to the institutionalization of translation where "hierarchical control is established; boundaries are maintained." Within this institution, according to Cronin (2002: 58), "[t]he role of interpreters throughout history has been crucially determined by the prevailing hierarchical constitution of power and their position in it."

These sociopolitical aspects of interpreting are patent in the hierarchical structure of interpreting and the role of each linguist group during the IMTFE. The background of the interpreting arrangements and the linguists who were involved in the interpreting process at the IMTFE is discussed below, focusing on issues of trust, power and control.

\section{International Military Tribunal for the Far East (IMTFE)}

The IMTFE is more commonly known as the Tokyo War Crimes Tribunal, or the Tokyo Trial. This was essentially the Japanese counterpart of the Nuremberg Trial. The IMTFE was established by the Charter of the IMTFE under the direction of US Army General Douglas MacArthur. It convened on May 3, 1946, and adjourned on November 12, 1948.

There were 28 "Class A" defendants, mostly military and political leaders in wartime Japan. A panel of 11 judges presided over the tribunal, one from each of the allied powers: the United States, the Soviet Union, the United Kingdom, France, the Netherlands, the Republic of China, Australia, New Zealand, Canada, India, and the Philippines. The president was the Australian judge Sir William Webb. The prosecution team, consisting of representatives from the allied powers, was led by Chief Prosecutor Joseph Keenan of the United States.

The indictment accused the defendants of "crimes against peace," "war crimes" and "crimes against humanity." During the trial, two of the defendants died of natural causes, and one had a nervous breakdown and was found incompetent to stand trial. The remaining 25 were all found guilty. Seven were sentenced to death by hanging, 16 to life imprisonment, and two to lesser terms.

\section{Interpreting arrangements at the IMTFE}

The use of interpreters and translators at the IMTFE was set forth by the tribunal charter. Under the heading "Fair Trial for Accused," Article 9 (b) states, "Language. The trial and related proceedings shall be conducted in English and in the language of the accused. Translations of documents and other papers shall be provided as needed and requested (Amended Charter of the International Military Tribunal for the Far East, April 26, 1946)."

Accordingly, interpreting between English and Japanese was offered throughout the proceedings, but Russian simultaneous interpreting was also provided as a standalone arrangement for the Soviet judge who did not understand English or Japanese. The tribunal also used interpreters of Chinese, French, Dutch, German, Russian and Mongolian when witnesses and prosecutors spoke in these languages.

IBM equipment, identical to that used at Nuremberg, was installed in the IMTFE. However, consecutive was the predominant mode of interpreting because 
the tribunal came to the conclusion that simultaneous interpreting between English and Japanese was impossible. The simultaneous mode was used only when the speaker read a document and its translation was available to the interpreter. In effect, this was nothing more than simultaneous reading of a prepared translation.

As previously discussed, the most salient feature of the interpreting arrangements at the IMTFE was the presence of three tiers of linguists. The first tier consisted of the interpreters who interpreted the proceedings. They were all Japanese nationals. The transcripts record a total of 27 Japanese-English interpreters, but only a handful of them worked regularly throughout the trial (Watanabe 1998: 10-11).

The second tier comprised the monitors. Four Nisei (second-generation Japanese Americans) worked as monitors. They monitored the interpretation, and interjected to correct interpreting errors, coordinate the turns of speakers and add explanations to the interpretation for the court participants. They also simultaneously read the translations of the indictment, the opening statements, the judgment (verdict) and other prepared statements.

The Language Arbitration Board was the last tier. This board consisted of one member appointed by the tribunal and one each by the defense and the prosecution, and ruled on any disputed translations and interpretations. The member appointed by the tribunal was designated the language arbiter, and announced the rulings in court. Two Caucasian military officers played this role at different times over the course of the trial.

\section{The tribunal's explanation of the Language Arbitration Board}

Why did the IMTFE have this three-tier system of linguists to address its interpreting needs? There is an official explanation in the judgment as to why the Language Arbitration Board was established: "Part a, Section I Establishment and Proceedings of the Tribunal" states,

[T] he need to have every word spoken in Court translated from English into Japanese, or vice versa, has at least doubled the length of the proceedings. Translations cannot be made from the one language into the other with the speed and certainty which can be attained in translating one Western speech into another. Literal translation from Japanese into English or the reverse is often impossible. To a large extent nothing but a paraphrase can be achieved, and experts in both languages will often differ as to the correct paraphrase. In the result the interpreters in Court often had difficulty as to the rendering they should announce, and the Tribunal was compelled to set up a Language Arbitration Board to settle matters of disputed interpretation (The Judgment of the International Military Tribunal for the Far East, November 1948).

This statement basically refers to the difficulty of interpreting between Japanese and English, and acknowledges that there can be more than one correct version in translations and interpretations. It does not, however, explain why the monitor was appointed, and why three different socio-ethnic groups were engaged in three different functions. In pursuit of an answer, let us examine the background of the interpreting arrangements at the IMTFE. 


\section{Military trials in Manila and Japanese interpreters at the IMTFE}

Prior to the establishment of the IMTFE on January 19, 1946, there were U.S. military trials against two Japanese generals, Tomoyuki Yamashita and Masaharu Homma, in Manila, the Philippines. Correspondences by the U.S. military concerning the interpreting at the trials and a book written by one of Yamashita's attorneys indicate that serious problems with the military interpreters were uncovered during the proceedings.

For example, there is a military correspondence that discusses three officers who had been appointed court interpreters but refused to take the interpreter's oath, citing their own lack of qualification in spoken Japanese (CINCAFPAC Manila 1945). In response to this incident, the Commander in Chief, Army Forces, Pacific, asks in a message dated October 28, 1945 (one day before the Yamashita trial convened), "Why was competent interpreter personnel not selected in sufficient time to prevent this outrageous failure?"

Yamashita had a personal interpreter named Masakatsu Hamamoto. The Harvard-educated Hamamoto had been a civilian interpreter attached to the Japanese army during the war. He was indispensable to the communications that took place outside the courtroom such as in discussions between Yamashita and his counsel and in Yamashita's psychiatric evaluations. But Hamamoto was not permitted to act as an official court interpreter because he was also a prisoner of war.

According to Reel (1971: 145-146), who was one of Yamashita's defense attorneys,

[t] he official court interpreters were divided into two groups - American Nisei soldiers, whose Japanese was fairly good when restricted to elementary or "kindergarten" expressions but whose English left much to be desired, causing them frequently to take liberties in altering counsel's questions to fit their knowledge of the languages, and a number of American naval and marine officers, whose English was excellent but whose Japanese was spotty and required constant use of translation dictionaries.

To address this problem, Hamamoto was permitted to sit beside Yamashita during the trial to do whisper-interpreting from English into Japanese. Reel (1971: 145-146) writes, "This was a tour de force of stupendous proportions that had the effect of shortening the proceedings by many weeks, for, without Hamamoto, the court interpreters would have had to translate the entire trial for the accused." Hamamoto, however, was not allowed to interpret Yamashita's testimony into English for the court.

The official interpreters' renditions were slow and required frequent pauses. Reel (1971: 14-15, 148) uses such adjectives as "painstaking," "bumbling" and "exasperating" in references to the official interpreters in his book. In addition, discussions over disputed interpretations took much of the time in court. There was even an incident in which newspaper reporters who had pointed out interpreting errors were called to testify in court and to elaborate on their opinions (Reel 1971: 45-49).

Yamashita was sentenced to death by hanging on December 7, 1945 (the fourth anniversary of the Pearl Harbor attack), and executed on February 23, 1946. Interviews with Takashi Oka (2005) and Masakazu Shimada (2000), who interpreted in more than 200 sessions during the IMTFE, confirm that the recruiting and testing of Japanese interpreters for the IMTFE took place in January and February 1946. 
Documents that explicitly link the interpreting problems in Manila to the tribunal's decision to open its interpreter search to Japanese nationals have not been located. A number of correspondences (in the Records of the Allied Operational and Occupation Headquarters, World War II in the National Archives), however, clearly suggest that the Legal Section of the Superior Commander of the Allied Powers (SCAP), which established the procedural guidelines of the IMTFE, was aware of the interpreting problems in Manila. The IMTFE could not afford to have the same problems, given the fact that it was an international forum and not a U.S. military trial, and that it had attracted close attention from all over the world. The tribunal must have recognized the need for competent interpreters, regardless of nationality or civilian status, who could facilitate smooth proceedings. This can explain the inclusion of Japanese nationals in the interpreting arrangements. This view is supported by Shimada's remarks (Shimada 2000: 20-21), discussed below.

\section{Nisei monitors}

Many of the recruited interpreters were diplomats with the Japanese Ministry of Foreign Affairs. Shimada was a former soldier with the Japanese Imperial Army. Given the fact that three foreign ministers, two diplomats and 17 military leaders were included among the 28 defendants, these interpreters were, in effect, interpreting in a trial in which their former superiors' lives were at stake.

Just as it is hard to imagine former Nazi members interpreting at Nuremberg, it is conceivable that the tribunal was concerned about its interpreters' "impartiality" and was loath to appear dependent on citizens of the defeated nation; hence, the tribunal decided to establish a system to regulate and control the interpreters' work. Documents that explicitly describe such concerns on the part of the tribunal and the decision to monitor the interpreting have not been found, but interviews with Shimada (2000) and Oka $(2005,2006)$ generally support such a supposition. According to Shimada (2000: 20-21), the tribunal's Language Section selected four Nisei to supervise the Japanese interpreters because the chief of the section did not understand the Japanese language.

The fact that all the prepared translations, such as the opening statements and the judgment, were rendered by the Nisei monitors indicates the tribunal's preference for using non-Japanese rather than Japanese citizens. Shimada says (2000: 34):

It was a given from the beginning, and it was expected. Whether it's the judgment or something else, it's the Americans who should be interpreting. Everything! But because they were not competent, Japanese were hired ... There were no such [capable American] people. Something formal, like the arraignment - things that were presented at the beginning and the end of the trial - were prepared in writing beforehand. They were translated, Japanese lawyers checked them, and Americans read [the translations at the trial]. So, we never said anything like "Tojo, death by hanging!"

\section{Language arbiter}

As cited in the judgment, the Language Arbitration Board was established as a "referee" to settle disputes over translations and interpretations. When a translation or interpretation was challenged by the defense or the prosecution, the tribunal presi- 
dent referred the matter to the language arbiter. After deliberation among the board members outside the courtroom, the language arbiter announced the ruling in the following court session. Major Lardner Moore was the first language arbiter. According to Moore (1980), a naturalized Japanese-American lawyer represented the prosecution, and a Japanese citizen who had been the editor of an English magazine represented the defense. Moore says he let these two members of the board discuss and agree on the rulings and merely reported their decisions to the court.

After Moore was discharged, Captain Edward Kraft assumed the arbiter position. The roster of the Military Intelligence Service Language School indicates that Kraft had studied Japanese in elementary level classes for only one year. According to Moore (1980), however, he was more involved in the board's deliberations and he "had his own ideas about what's to be done."

The Language Arbitration Board probably served to minimize the time spent discussing interpreting and translation disputes in court. In addition, the language arbiter most likely kept an eye on the monitors as well. The monitors were all Kibei (Nisei who received education in Japan and returned to the United States), who suffered even greater prejudice than other Japanese Americans, as they were suspected of being "pro-Japanese" (Kono 2003). Three of the four monitors had been sent to internment camps after the Pearl Harbor attack. Although they volunteered from the camps to go to the U.S. military's Japanese language school to teach or train for military intelligence, they had to fight prejudice and suspicions of disloyalty within the U.S. military while they served in the Pacific (McNaughton 1994). Kawamoto (2005), who worked as a translator at the IMTFE, discusses the resentment he felt when he was sent to the Pacific from the language school with a dog tag that had the address of the internment camp where his parents were detained. The SCAP may have been concerned that these monitors were sympathetic to the Japanese defendants because of their background, and thus wanted to deter them from being too accommodating of the defendants' needs. The language arbiter, a Caucasian military officer, may have functioned to address such concerns, and to give the appearance that the U.S. military was in charge of the procedure.

The absence of high-ranking Japanese Americans at the time could explain in part why Caucasian military officers fulfilled the role as language arbiter. Organizational planning documents of the tribunal (in the Records of the Allied Operational and Occupation Headquarters, World War II in the National Archives) called for an officer of a specific military rank to fill each of the high positions in respective sections, including the Language Section. Designated as "enemy aliens," Japanese Americans were never allowed in the Navy's elite Japanese language schools (Slesnick 2006: 2-3). Even those who went to the Army's language school were not commissioned until toward the end of the war. This war-time segregation may explain the absence of Nisei in higher positions in the tribunal's Language Section as well.

\section{Modern-day parallels?}

In today's context, the trustworthiness of translators and interpreters is sometimes discussed in the U.S.-led intelligence and military activities. For example, one of the major reasons the U.S. government has not been able to recruit enough Arabic translators and interpreters for its war and intelligence efforts is the requirement of a 
top-secret security clearance (Reed 2005). A defense contractor which supplies translators and interpreters of Arabic, Pashto, Dari, etc. also requires the applicants to hold a U.S. passport and pass the government's security check and "counterintelligence/force protection screening" (L-3 Titan 2006). These efforts can be viewed as a system to regulate and control interpreters in order to assure their trustworthiness.

As for the contemporary war crimes trials or military trials, any systematic monitoring of interpreters' performance has hardly been documented. ${ }^{3}$ Although trust, power and control issues in interpreting are still relevant in today's context, the monitoring system at the IMTFE should probably be considered as a special case. It involved a variety of complex elements, such as the use of a lesser learned language, the absence of professionally trained interpreters, the political nature of the setting, and race issues.

\section{Conclusion}

In the socio-political context, when a party in power has to rely on interpreters who do not have shared interest or affiliation, the party may set up a system to regulate and control the interpreters out of concerns over their trustworthiness. This scenario is evident in the case of the IMTFE: The tribunal wanted to use U.S. military personnel as interpreters, but it found them incompetent and had to resort to bilingual Japanese nationals. The tribunal did not trust the "impartiality" of those Japanese interpreters, and was loath to appear dependent on citizens of the defeated nation. So, it used four Japanese Americans to monitor the interpretation. The language arbiter (a Caucasian U.S. army officer) may also have functioned to keep an eye on the Japanese American monitors, who may have been suspected of being sympathetic to the accused, and to maintain the appearance that the U.S. military was in charge. In sum, this hierarchical structure of linguists functioned as a display of authority and a check against any "bad faith" harbored by those who didn't seem to share the same interests with the tribunal.

Although the transcripts show that the monitors did correct some interpreting errors, they also indicate that there were a number of unnecessary or incorrect interjections by the monitors (Takeda 2007). The incompetence of some monitors is referred to in Shimada's interview $(2000: 21,23)$ as well. Asked if he believed that the monitors were needed for achieving a higher level of accuracy, Oka (2006) answered, "Whether or not the monitoring was needed has nothing to do with interpreting. It was a political matter. In a nutshell, [the tribunal] didn't fully trust the Japanese interpreters, and that's why the monitor and the language board were established." As Lefevere (1992: 2) suggests, it may be "important to remember that trust is invested in the producer of the translation, not necessarily in the product itself." In some political settings, "[t]rust may be more important than quality."

\section{NOTES}

* A previous version of this paper was presented at the New Research in Translation and Interpreting Studies conference in Tarragona, Spain, in 2005.

1. Personnel who engaged in language-related functions at the IMTFE were called "linguists." Therefore, the term "linguists" is used in this study to refer to language-related personnel and not to persons who study linguistics.

2. The author's translations from Japanese. 
3. One method to check the interpreter's performance has been reported (Regulatory Intelligence Data, April 4, 2006): When the military commission failed to provide an interpreter for a terrorist suspect and had to rely on the defense team's interpreter at Guantanamo Bay, the audio of the interpretation was later checked by the commission to verify the accuracy.

4. The author's translations from Japanese.

\section{REFERENCES}

Aвate, Tom (2006): INNOVATIONS; Military getting high-tech help from SRI lab. San Francisco Chronicle. May 29, 2006.

Album and Roster of the Military Intelligence Service Language School. Provided by Grant Ichikawa of the Japanese American Veterans Association in December 2005.

Anderson, R. Bruce (1976): Perspectives on the role of interpreter. In: Richard W. BRislin, ed. Translation: Applications and Research. New York: Gardner Press, 208-228.

Bowen, Margareta et al. (1995): Interpreters and the making of history. In: Jean DeLisLe and Judith Woodsworth, eds. Translators through History. Amsterdam: John Benjamins Publishing, 245-280.

CINCAFPAC Manila (1945): A correspondence to CINCAFPAC ADV. October 27, 1945. Records of the Allied Operational and Occupation Headquarters, World War II (Record Group 331). National Archives and Records Administration. College Park, MD.

CINCAFPAC ADV. (1945). A correspondence to CINCAFPAC Manila. October 28, 1945. Records of the Allied Operational and Occupation Headquarters, World War II (Record Group 331). National Archives and Records Administration. College Park, MD.

Cronin, Michael (2002): The empire talks back: orality, heteronomy, and the cultural turn in interpretation studies. In: Maria Tyмосzко and Edwin Gentzler, eds. Translation and Power. Amherst and Boston: University of Massachusetts Press, 45-62.

Gaiba, Francesca (1998): The Origins of Simultaneous Interpretation: The Nuremburg Trial. Ottawa: University of Ottawa Press.

Hermans, Theo (2000): Shall I Apologize Translation. Visited January $27^{\text {th }}, 2009$, $<$ http://eprints.ucl.ac.uk/archive/00000516/01/Ep_Apologizetrans.pdf >.

Kono, Rikako (2003): The identity of a kibei-nisei: the life of Akira Itami. Ferris Wheel. 6:82102.

L-3 Communications Titan Group. Working at L-3 Communications Titan. Visited on January $27^{\text {th }}, 2009,<$ http://www.titan.com/carrers/linguists.html $>$.

LASTER, Kathy and TAYLOR, Veronica (1994): Interpreters and the Legal System. Leichhardt: The Federation Press.

Lefevere, André (1992): Introduction. In: Andre Lefevere, ed. Translation/History/Culture, London: Routledge.

Lewis, Bernard (2004): From Babel to Dragomans: Interpreting the Middle East. Oxford: Oxford University Press.

McNaughton, James, C. (1994): Nisei Linguists and New Perspectives on the Pacific War: Intelligence, Race, and Continuity. Visited in October $22^{\text {nd }}, 2005,<\mathrm{http}: / / \mathrm{www} \cdot \operatorname{army} \cdot \mathrm{mil} / \mathrm{CMH}-$ PG/topics/apam/Nisei.htm>.

MORRIS, Ruth (1999): The gum syndrome: predicaments in court interpreting. Forensic Linguistics. 1(1):6-29.

PyM, Anthony (1999): Method in Translation History. Manchester: St. Jerome.

ReED, Cheryl L. (2005): Government wages uphill battle in search for Arabic translators. Chicago Sun Times, December 18, 2005.

Reel, A. Frank (1949/1971): The Case of General Yamashita. New York: Octagon Books.

SLESNICK, Irwin L. and SLESNICK, Carole E. (2006): Kanji \& Codes: Learning Japanese for World War II. Bellingham. Published by the authors.

TAKEDA, Kayoko (2007): Sociopolitical Aspects of Interpreting at the International Military Tribunal for the Far East (1946-1948). Unpublished doctoral dissertation. Universitat Rovira i Virgili. 
Watanabe, Tomie (1998): Tokyo Saiban no Tsuyaku Kenkyu: Tojo Hideki Shogen o Tsujite.

Unpublished master's thesis. Daito Bunka University.

Zarakhovich, Yuri (2005): Signs of the times. Time Europe. October 10, 2005.

\section{INTERVIEWS}

Interview with Yukio Kawamoto by the author, Springfield, Virginia, March $20^{\text {th }}, 2005$.

Interview with Lardner W. Moore by George E. Moore, Oregon, 1980. Transcribed by Kaede Johnson in 2005.

Interview with Takashi Oka by the author, Washington D.C., December $11^{\text {th }}, 2005$.

Interview with Masakazu Shimada by Masaomi Kondo and Tomie Watanabe. "Booth no naka no Itami Akira." Daito Forum. 13:16-35, 2000.

E-mail communication with Takashi Oka by the author, April-May, 2006. 